\title{
Michele R. McPhee, Maximum Harm: The Tsarnaev Brothers, The FBI, and the Road to the Marathon Bombing (ForeEdge, 2017)
}

\section{reviewed by Tim Wilson}

\section{(cc) BY}

This work is licensed under a Creative Commons Attribution 3.0 License.

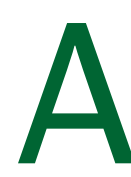

t 2.49 p.m. on April 152013 two home-made bombs wreaked carnage at the annual Boston Marathon.

As a symbolic target of jihadist terror, the marathon's finishing line area was particularly well chosen:

a crowd celebrating individual runners' achievements under an array of international flags symbolised an entire Western-led global order. Three died in these explosions; hundreds more were injured (of whom no less than 17 lost limbs). Two more policemen were to die in the four-day manhunt that followed before the bombers, Chechen-American brothers, Dzhokhar and Tamerlan Tsarnaev, were finally stopped. General rejoicing greeted the news that Tamerlan had been killed, and Dzhokhar arrested. As Michele McPhee comments simply: 'I know a lot of police officers who didn't have to pay for a round of beers that night' (p. viii).

Ultimately, though, McPhee's account of the Boston atrocity leaves the reader with notably little sense of reassurance. First, she is a blunt writer who is not afraid to tell it like it was. Her account of the injuries caused by the bombings which drove red-hot shrapnel through the bodies of spectators and runners makes for genuinely uncomfortable reading. All too often, mere death tolls dominate assessments of terrorist attacks; by contrast, this graphic account points all too starkly at the importance of the wider penumbra of injury - the multiple lives that will continue, but which have been changed for ever in an instant.

Second, she is a diligent and tenacious researcher. Her findings on the Tsarnaev family, granted political asylum in the USA in 2002, are here rather startling. The key figure here quickly emerges as the elder brother, Tamerlan. His terrorist career, as so often with so-called 'homegrown' jihadists, turns out to have been an unedifying one. Aged 26 at his death, he had never held a proper job; yet he drove a Mercedes and had embarked on starting a family. Despite apparent implication in a grisly drugs-related triple homicide back in 2011, he had escaped investigation. Despite not holding a valid US passport and having his name on two terror watch lists, he was allowed to travel to Russia for six months in 2012; and, even more pertinently, to return without hitch to the USA. McPhee suggests, in short, that 'Tamerlan got away with so much villainy that only a hands-off policy formulated at the local level by one or more agencies responsible for national intelligence could have engineered it' (p. x). Thus, McPhee makes an argument for viewing Tamerlan as (most likely) a disappointed FBI informant on jihadism who had turned against his handlers when he had failed to achieve American citizenship. This is a forcefully made case: though ultimately, of course, one that must unavoidably rest upon circumstantial evidence.

Stylistically, this is a dense book in places: and occasionally, its 'thick description' risks becoming positively viscous. But it does succeed in demonstrating what well-informed, locally-grounded, diligent journalism has to offer the academic study of both terrorism and counter-terrorism; and, most importantly of all, what it can potentially illuminate about their tangled inter-relationship. McPhee thus deserves our gratitude: her 
The Centre for the Study of Terrorism and Political Violence

\section{Journal of Terrorism Research}

book will surely become the standard 'go to' study both of the Boston atrocity of 2013, and of its very murky genesis.

About the reviewer: Dr Tim Wilson is the Director for the Centre for the Study of Terrorism and Political Violence and a Senior Lecturer in the School of International Relations at the University of St Andrews 